ЛАПІКА А.О.

\title{
АДМІНІСТРАТИВНО-ПРАВОВИЙ МЕХАНІЗМ РЕАЛІЗАЦІЇ ПОВНОВАЖЕНЬ МІСЦЕВИХ ДЕРЖАВНИХ АДМІНІСТРАЦІЙ В ГАЛУЗІ БЮДЖЕТУ ТА ФІНАНСІВ
}

\section{ADMINISTRATIVE AND LEGAL MECHANISM OF IMPLEMENTATION OF POWERS OF LOCAL STATE ADMINISTRATIONS IN THE FIELD OF BUDGET AND FINANCE}

\begin{abstract}
У статті розглянута актуальна проблема застосування адміністративно-правового механізму реалізації повноважень місцевих державних адміністрацій у галузі бюджету та фінансів. Обгрунтовано роль місцевих державних адміністрацій щодо формування і використання місцевих фінансів. Мета статті - охарактеризувати адміністративно-правовий механізм реалізації повноважень місцевих державних адміністрацій у галузі бюджету та фінансів. Виділено елементи адміністративно-правового механізму реалізації повноважень місцевих державних адміністрацій у галузі бюджету та фінансів: норми права, нормативно-правові акти, принципи фінансування місцевих бюджетів, бюджетне регулювання, реалізація прав, правовідносини, юридична відповідальність. Доведено необхідність реформування механізму адміністративно-правового регулювання діяльності місцевих державних адміністрацій у галузі бюджету та фінансів. Виділено принципи фінансування місцевих бюджетів, зокрема такі: прогнозованості, плановості, самостійності, збалансованості, субсидіарності, гнучкості, справедливості, контролювання, ефективності, публічності. Адміністративно-правовий механізм реалізації повноважень місцевих державних адміністрацій у галузі бюджету та фінансів представлений сукупністю структурних елементів, які взаємодіють між собою та спрямовані на виконання соціально-економічної функції держави стосовно розвитку місцевих громад. Важливо відзначити, що з'єднуючим складником $\epsilon$ адміністративно-правові норми, які визначають обов'язки відповідних суб'єктів публічних відносин стосовно формування доходів і видатків місцевих бюджетів, а також засоби та принципи такої діяльності, що дає можливість ефективно забезпечити реалізацію державної економічної політики. Окреслено важливі напрями, які стоять перед адміністративно-правовим механізмом реалізації повноважень місцевих державних адміністрацій у галузі бюджету та фінансів: 1) розробка сучасної моделі контрольно-наглядової діяльності за виконанням місцевого бюджету; 2) децентралізація повноважень та фінансових потоків; 3) запровадження заходів безпеки у бюджетний процес; 4) приведення чинного законодавства у відповідність зі змінами державної економічної політики у цій сфері, які визначені в урядових документах; 5) утворення нового органу - громадської спостережної ради за розподілом коштів місцевого бюджету. Визначено повноваження та правові засади діяльності місцевих державних адміністрацій у галузі бюджету та фінансів.
\end{abstract}

Ключові слова: адміністративно-правовий механізм, місиева державна адміністрачія, повноваження, місиевий бюджет, місиеві фінанси. 
The article considers the current problem of application of the administrative and legal mechanism for the implementation of the powers of local state administrations in the field of budget and finance. The role of local state administrations in the formation and use of local finances is substantiated. The purpose of the article is to describe the administrative and legal mechanism for exercising the powers of local state administrations in the field of budget and finance. Elements of the administrative-legal mechanism of realization of powers of local state administrations in the field of budget and finance are allocated: norms of law, normative-legal acts, principles of financing of local budgets, budgetary regulation, realization of rights, legal relations, legal responsibility. The necessity of reforming the mechanism of administrative and legal regulation of local state administrations in the field of budget and finance is proved. The principles of financing local budgets are highlighted, in particular the following: predictability; planning; independence; balance; subsidiarity; flexibility; justice; control; efficiency; publicity. The administrative and legal mechanism for exercising the powers of local state administrations in the field of budget and finance is represented by a set of structural elements that interact with each other and are aimed at fulfilling the socio-economic function of the state in relation to local community development. It is important to note that the connecting component is the administrative and legal norms that define the responsibilities of the relevant subjects of public relations in relation to the formation of revenues and expenditures of local budgets, as well as the means and principles of such activities that enable effective implementation of state economic policy. The important directions facing the administrative and legal mechanism for the implementation of the powers of local state administrations in the field of budget and finance are outlined: 1) development of a modern model of control and supervision over the implementation of the local budget; 2) decentralization of powers and financial flows; 3 ) introduction of security measures in the budget process; 4) bringing the current legislation in line with changes in state economic policy in this area, which are defined in government documents; 5) formation of a new body - a public supervisory board for the distribution of local budget funds. The powers and legal bases of local state administrations in the field of budget and finance are determined.

Key words: administrative-legal mechanism, local state administration, powers, local budget, local finances.

Постановка проблеми. Вибраний шлях розвитку демократії в Україні передбачає публічність і підзвітність виконавчих органів влади. Реалізація регіональної економічної політики в умовах поширення процесів децентралізації влади вимагає перегляд наявних взаємозв'язків місцевих державних адміністрацій і механізму їх адміністративно-правового регулювання. Саме місцеві державні адміністрації несуть відповідальність за соціально-економічний розвиток місцевих громад. Місцеві державні адміністрації виконують важливу роль 3 формування і використання місцевих фінансів. Виконання місцевих бюджетів передбачає видатки на охорону здоров'я, освіту, культуру, розвиток інших суспільно значимих сфер для громадян. На жаль, має місце постійний дефіцит коштів у регіонах, певною мірою зумовлений неефективним управлінням місцевими фінансами, який покривається із державного бюджету.

За таких умов наявний механізм адміністративно-правового регулювання діяльності місцевих державних адміністрацій у галузі управління бюджетом та фінансами $є$ неефективним, негнучким. Тому назріла нагальна потреба його організаційно-правового оновлення в контексті реалізації реформ щодо децентралізації влади і передачі більших владних повноважень державним місцевим адміністраціям, що робить актуальною тему цього дослідження.

Аналіз останніх досліджень та публікацій. Серед наукових робіт з адміністративного права заслуговують на увагу праці таких учених, як: О.О. Бойко-Слобожан, I.I. Єфремова, П.П. Латковський, А.А. Манжула та інші. В юридичній науці дослідження проблем діяльності місцевих державних адміністрацій було розглянуто у працях таких учених: В.Б. Авер'янова, А.М. Коваленка, В.В. Копейчикова, Ю.В. Мельника, О.І. Остапенка, Н.Г. Плахотнюк, В.Ф. Погорілка, А.Ф. Ткачука, О.Ф. Фрицького та інших. Серед кола науковців, що досліджували фінансово-правове регулювання виконання місцевих бюджетів, варто загадати таких як: I.I. Попадинець, I.М. Проць, О.О. Хом’якова, О.В. Чинчин та інші. 
На жаль, грунтовних наукових досліджень щодо вирішення проблемних питань реалізації адміністративно-правового механізму реалізації повноважень місцевих державних адміністрацій у галузі бюджету та фінансів не досить, що потребує подальшого вивчення і пошуку шляхів розв'язання.

Мета статті - охарактеризувати адміністративно-правовий механізм реалізації повноважень місцевих державних адміністрацій у галузі бюджету та фінансів.

Виклад основних результатів дослідження. Місцева державна адміністрація є органом, який уособлює і здійснює виконавчу владу на території відповідної адміністративно-територіальної одиниці країни і реалізує державну економічну політику в межах своїх повноважень. На жаль, діяльність місцевих державних адміністрацій останніми роками виявилась неефективною, особливо у сфері фінансових відносин, що зумовлює постійне недофінансування державних установ у сфері освіти, медицини, культури і спорту, а така ситуація потребує нагальних змін.

Сутність поняття «механізм адміністративно-правового регулювання» зумовлена специфікою правових засобів, методів і форм його здійснення.

Дослідниця О.Ф. Скакун під правовим регулюванням розуміє «здійснюване державою за допомогою права і сукупності правових засобів упорядкування суспільних відносин, їх юридичне закріплення, охорону та розвиток» [36, с. 488].

На нашу думку, механізм реалізації повноважень місцевих державних адміністрацій у галузі бюджету та фінансів являє собою адміністративно-управлінські методи та засоби впливу, спрямовані на реалізацію публічних відносин щодо формування місцевого бюджету та фінансів.

Г.В. Дмитренко справедливо зазначає, що місцеві бюджети - це не просто балансові розрахунки доходів і витрат, які мобілізуються і витрачаються на відповідній території, ай важлива фінансова категорія, основу якої становить система фінансових відносин, що складається між місцевими та державним бюджетами, а також усередині сукупності місцевих бюджетів. Місцеві бюджети $\epsilon$ головним каналом доведення до населення кінцевих результатів суспільного виробництва, спрямованих на суспільне споживання. Саме через них суспільні фонди споживання розподіляються в територіальному розрізі, тобто між окремими адміністративно-територіальними одиницями i соціальними групами населення. Крім того, саме з місцевих бюджетів фінансується розвиток галузей виробничої сфери, насамперед місцева промисловість і комунальне господарство [4, с. 120].

Варто зауважити, що формування місцевого бюджету місцевими державними адміністраціями має здійснюватися на основі відповідних принципів державного регулювання економіки.

Економічний словник Й.С. Завадського, Т.В. Осовської, О.О. Юшкевич дає таке визначення: принцип (англ. principle) - головне, вихідне положення, правило діяльності організації в якій-небудь сфері або правило поведінки особи [6, с. 250].

Наприклад, головними принципами державного регулювання економіки О.М. Чечель вважає: науковість, погодження інтересів, цілеспрямованість, пріоритетність, доцільність, системність, комплексність, принцип гнучкості й адаптації, достатності, принципи організаційно-правового й економіко-організаційного забезпечення, а також принципи поступовості та етапності державного регулювання економіки, пріоритету права над економікою, єдності економіки і політики, ефективності, прозорості, відповідальності [37, с. 107-108].

Н.А. Панчук [14] виокремив такі принципи державного регулювання економіки, як: системність, безперервність, єдність розвитку, обгрунтованість, об'єктивність, економічність, обов'язковість, професіоналізм.

Варто зазначити, що державний і місцеві бюджети є важливою складовою частиною національної економіки. Тому саме на принципах державного регулювання економіки функціонує бюджетна система.

Науковець 3.І. Перощук справедливо вказує, що «принципи правового регулювання бюджетної системи України $є$ аспектом особливого вияву загальних принципів права і являють собою вихідні ідеї, основні, найбільш загальні та керівні положення, які у сукупності визначають вихідні позиції для правового регулювання суспільних відносин, що виникають у процесі складання, розгляду, затвердження, виконання бюджетів, звітування про їх виконання та контролю за дотриманням бюджетного законодавства, а також питання відповідальності за порушення бюджетного законодавства» [15 с. 150].

Згідно зі статтею 7 Бюджетного кодексу України, бюджетна система України грунтується на таких принципах: єдності бюджетної системи України, збалансованості, самостійності, повноти, обгрунтованості, ефективності та результативності, принципу субсидіарності, цільового використання бюджетних коштів, справедливості і неупередженості, публічності та прозорості [2]. 
Науковці Інституту політичної освіти виділяють основні принципи державного бюджету: бюджет є моделлю фінансової прозорості; кошти чітко прив'язуються до видів діяльності ії результатів; зрозумілість для громадян; спірні питання чітко визначені; усебічна загальна інформація на підтримку бюджетних рекомендацій [38, с. 21].

Окрім вищезазначених, К.В. Захожай запропоновала доповнити принципи бюджетної системи (Держбюджету України) ще двома додатковими: принципом економічної безпеки держави та принципом соціального захисту населення [7, с. 53].

На основі вивчених принципів державного регулювання економіки нами виділено принципи фінансування місцевих бюджетів, зокрема такі:

- прогнозованості (розроблення прогнозу бюджетного дефіциту та профіциту, прогнозу доходів та витрат на майбутній період);

- плановості (планування статей доходів та видатків на основі реальних макро- і мікроекономічних показників, складання плану виконання бюджету на місяць, квартал, півріччя, рік);

- самостійності (місцеві бюджети є самостійними та повними);

- збалансованості (встановлення рівноваги надходжень та видатків, регулювання бюджетного процесу);

- субсидіарності (передбачає пропорційний розподіл усіх видів видатків, поділ на статті, узгодження між державним бюджетом та місцевими бюджетами);

- гнучкості (можливість залучати додаткові джерела грошових надходжень до бюджету 3 передбачених джерел та резервного фонду, оцінка допустимих відхилень);

- справедливості (місцевий бюджет формується на засадах справедливого і доцільного розподілу національного багатства, ресурсів між громадянами і територіальними громадами);

- контролювання (передбачає співставлення і порівняння доходів і витрат за встановлений період, перевірку виконання статей бюджету, складання звіту);

- ефективності (економія витрат, цільове спрямування бюджетних коштів, пошук джерел для додаткового залучення коштів, податкове регулювання, встановлення ліміту витрат);

- публічності (передбачає відкритість і доступність інформації для місцевих громад щодо всіх статей бюджету, надходжень та видатків за календарний період, звітування про витрачання коштів, врахування пропозицій та побажань громадськості).

Держава визначає на законодавчому рівні форми мобілізації фінансових ресурсів, розподіляючи й перерозподіляючи доходи і витрати бюджету. Принципи фінансування місцевих бюджетів лежать в основі національної економічної політики.

Р.Г. Долінська справедливо вважає, що головне призначення фінансової політики - забезпечення відповідними фінансовими ресурсами державної програми соціально-економічного розвитку суспільства [5, с. 11]. У фінансовій діяльності беруть участь усі державні органи законодавчої і виконавчої влади. Загальне стратегічне управління державними фінансами здійснюють органи законодавчої влади: Верховна Рада України, Верховна Рада Автономної Республіки Крим, органи місцевого самоврядування, а також виконавчої влади: Кабінет Міністрів України, Рада Міністрів Автономної Республіки Крим, обласні і районні державні адміністрації. Вони здійснюють свої повноваження у відповідності до Конституції України, Бюджетного кодексу, законів України [5, с. 15].

Відповідно, держава провадить фінансову політику як на національному рівні, так і на регіональному рівні, де провідну роль у цьому процесі відіграють місцеві державні адміністрації, оскільки останні забезпечують соціально-економічний розвиток місцевих громад. Варто зазначити, що місцеві державні адміністрації мають широкі повноваження в галузі бюджету та фінансів, що закріплено в Бюджетному кодексі України від 8 липня 2010 року № 2456-VI [2]; Законі України «Про місцеве самоврядування в Україні» від 21 травня 1997 року № 280/97-ВР [31]; Законі України «Про місцеві державні адміністрації» від 09 квітня 1999 року № 586-XIV [32].

Місцеві державні адміністрації управляють місцевим бюджетом, відстоюючи інтереси громади і держави, здійснюючи розподіл фінансів. Повноваження місцевих державних адміністрацій у галузі бюджету та фінансів регулюються за допомогою відповідного адміністративно-правового механізму.

На думку Ю.В. Кривицького, під механізмом правового регулювання потрібно розуміти систему правових засобів, за допомогою яких забезпечується стабільність суспільних відносин шляхом найбільш оптимального поєднання індивідуальних, громадських та державних інтересів членів соціуму з метою створення умов для прогресивного розвитку кожної особистості [9, с. 78].

Л.В. Лисяк визначає бюджетне регулювання як метод державного економічного регулювання економіки, який передбачає оптимальне співвідношення між державними доходами (пере- 
дусім податковими надходженнями) та державними витратами, а також перерозподіл коштів між різними бюджетами 3 метою впливу на циклічний розвиток економіки, на структурні зрушення в економіці, темпи науково-технічного прогресу, економічну та соціальну політику держави, співвідношення сукупного попиту та пропозиції [11].

Т.А. Бойко визначає зміст бюджетного регулювання. Бюджетне регулювання передбачає законодавчо закріплені відсоткові відрахування від загальнодержавних податків, зборів і обов’язкових платежів, встановлені на такій території, а також дотації і субвенції до бюджетів адміністративних територій відповідно до техніко-економічних обгрунтувань, в які включаються: статистичні дані про економічний, соціальний, природний та екологічний стан зазначених регіонів; розрахунки необхідних витрат для вирівнювання економічного, соціального й екологічного стану та ефективного використання природних ресурсів територій; інформація про урядові та регіональні програми подолання нерівностей між адміністративними територіями, про виконані в попередні роки програми й досягнуті результати про чинні програми та програми, що розробляються, $з$ прогнозом наслідків їх виконання [1, с. 15].

Процес бюджетного регулювання у системі соціально-економічного розвитку, на думку I.I. Вовчок, має бути спрямований на формування фінансової самодостатності територіальних громад, посилення конкурентоспроможності регіонів, пошук резервів економічного розвитку областей, підвищення продуктивності економіки регіонів, покращення добробуту населення [3].

Науковець О.М. Куракін виділяє такі елементи механізму правового регулювання, як: норма права, юридичні факти, правові відносини, правосуб'єктність, правосвідомість, законність, правова поведінка, правомірна поведінка [10, с. 27$].$

Варто зауважити, що принципи фінансування місцевих бюджетів є ядром адміністративно-правового механізму реалізації повноважень місцевих державних адміністрацій у галузі бюджету та фінансів.

Науковці $[7 ; 9 ; 10 ; 11 ; 12 ; 15 ; 17 ; 37]$ виділяють такі елементи адміністративно-правового механізму реалізації повноважень місцевих державних адміністрацій у галузі бюджету та фінансів, як:

- норми права, що визначають моделі правової поведінки суб'єктів публічних відносин стосовно формування доходів і видатків місцевих бюджетів;

- нормативно-правовий акт - офіційний документ, затверджений законодавчою владою держави, що надає правовій нормі юридичного статусу та є обов'язковим до виконання суб'єктів публічних відносин стосовно формування доходів і видатків місцевих бюджетів;

- принципи фінансування місцевих бюджетів, які визначають основні засади реалізації національної та регіональної економічної політики;

- бюджетне регулювання, що передбачає комплекс заходів, спрямованих на оптимальне регулювання рівня доходів та видатків місцевих бюджетів, а також перерозподіл коштів між різними бюджетами 3 метою реалізації соціально-економічних програм розвитку місцевих громад;

- реалізація прав - застосування правових норм шляхом виконання вимог чинного законодавства, які регулюють права та обов'язки суб'єктів у галузі бюджету та фінансів.

- правовідносини - різновид суспільно-економічних відносин, які виникають між суб'єктами в галузі бюджету та фінансів і регулюються нормами права;

- юридична відповідальність є мірою державного контролю та примусу з боку правоохоронних органів і громадських організацій, яка застосовується до тих державних службовців, які вчинили правопорушення в галузі бюджету та фінансів.

Усі елементи адміністративно-правового механізму реалізації повноважень місцевих державних адміністрацій у галузі бюджету та фінансів взаємопов’язані і взаємодіють між собою, спрямовані на координацію суспільних відносин стосовно розподілу коштів на потреби місцевої громади.

Для більш глибокого розуміння змісту діяльності державних місцевих адміністрацій стосовно формування та розподілу державних коштів доцільно виділити і класифікувати їх владні повноваження.

Зазначимо, що повноваження та порядок діяльності місцевих державних адміністрацій викладені в Законі України «Про місцеві державні адміністрації» від 9 квітня 1999 року № 586-XIV [32]. Зокрема, глава 2 «Основні галузеві повноваження місцевих державних адміністрацій» містить перелік повноважень місцевих державних адміністрацій в усіх галузях соціально-економічного розвитку місцевих громад, а саме: соціально-економічного розвитку (стаття 17); бюджету та фінансів (стаття 18); управління майном, приватизації, сприяння розвитку підпри- 
ємництва та здійснення державної регуляторної політики (стаття 19); містобудування, житлово-комунального господарства, побутового, торговельного обслуговування, транспорту і зв'язку (стаття 20); використання та охорони земель, природних ресурсів і охорони довкілля (стаття 21); науки, освіти, охорони здоров'я, культури, фізкультури і спорту, материнства і дитинства, сім'ї та молоді (стаття 22); соціального забезпечення та соціального захисту населення (стаття 23); зайнятості населення, праці та заробітної плати (стаття 24); забезпечення законності, правопорядку, прав і свобод громадян (стаття 25); міжнародних та зовнішньоекономічних відносин (стаття 26); оборонної роботи (стаття 27) [32].

О.П. Кириленко доводить, що однією з головних підвалин кожного демократичного режиму є державні місцеві адміністрації, функціонування яких здійснюється на засадах самостійності і фінансової незалежності. Практика діяльності органів місцевого самоврядування в умовах легітимізації їх прав довела, що саме фінансова незалежність є вирішальною у здійсненні функцій і завдань, які на них покладаються [12, с. 62].

Саме на місцеві державні адміністрації покладено обов'язки щодо формування і розподілу місцевих бюджетів в інтересах територіальних громад.

Відповідно до мети нашого дослідження розглянемо детальніше повноваження місцевої державної адміністрації в галузі бюджету та фінансів, визначених у статті 18 Закону України «Про місцеві державні адміністрації» від 9 квітня 1999 року № 586-XIV:

1) складає, схвалює і подає на розгляд ради прогноз відповідного бюджету, складає і подає на затвердження ради проєкт відповідного бюджету та забезпечує його виконання; звітує перед відповідною радою про його виконання;

2) подає в установленому порядку до органів виконавчої влади вищого рівня фінансові показники і пропозиції до проєкту Державного бюджету України, пропозиції щодо обсягу коштів Державного бюджету України для їх розподілу між територіальними громадами, розмірів дотацій і субсидій, дані про зміни складу об'єктів, що підлягають бюджетному фінансуванню, баланс фінансових ресурсів для врахування їх у разі визначення розмірів субвенцій, а також для бюджетного вирівнювання, виходячи із забезпеченості мінімальних соціальних потреб;

3) отримує від усіх суб’єктів підприємницької діяльності незалежно від форм власності інформацію, передбачену актами законодавства для складання і виконання бюджету;

4) здійснює фінансування підприємств, установ та організацій освіти, культури, науки, охорони здоров'я, фізичної культури і спорту, соціального захисту населення, переданих у встановленому законом порядку в управління місцевій державній адміністрації вищими органами державної та виконавчої влади або органами місцевого самоврядування, що представляють спільні інтереси територіальних громад, а також заходів, пов'язаних із розвитком житлово-комунального господарства, благоустроєм та шляховим будівництвом, охороною довкілля та громадського порядку, інших заходів, передбачених законодавством;

5) у спільних інтересах територіальних громад об'єднує на договірній основі бюджетні кошти з коштами підприємств, установ, організацій та населення для будівництва, розширення, реконструкції, ремонту та утримання виробничих підприємств, транспорту, мереж тепло-, водо-, газо-, енергозабезпечення, шляхів, зв'язку, служб з обслуговування населення, закладів охорони здоров'я, торгівлі, освіти, культури, соціального забезпечення житлово-комунальних об'єктів, у тому числі їх придбання для задоволення потреб населення, та фінансує здійснення цих заходів;

6) здійснює в установленому порядку регулювання інвестиційної діяльності;

7) визначає і встановлює норми споживання у сфері житлово-комунальних послуг, здійснює контроль за їх дотриманням [32].

В.А. Панченко, Я.В. Галета, О.В. Черненко справедливо зазначають, що відповідальність і повноваження мають бути збалансованими із підзвітністю [13, с. 87]. 3 огляду на зазначене вище, на нашу думку, місцеві державні адміністрації повинні публічно звітувати перед Кабінетом Міністрів України, Міністерством фінансів України, Міністерством розвитку економіки, торгівлі та сільського господарства про надходження і використання бюджетних коштів за звітний період.

Нами встановлено, що механізм формування та розподілу державних коштів державних місцевих адміністрацій грунтується на низці нормативно-правових актів України, таких як:

1) Конституція України від 28 червня 1996 року [8] - статті 118, 119, 140, 142;

2) Кодекси України: Бюджетний кодекс України від 8 липня 2010 року № 2456-VI [2]; Податковий кодекс України від 2 грудня 2010 року № 2755-VI [16];

3) закони України: «Про місцеві державні адміністрації» від 9 квітня 1999 року № 586-XIV [32]; «Про Державний бюджет України (на 2021 рік)» від 15 грудня 2020 року № 1082-IX [18]; 
«Про стимулювання розвитку регіонів» від 8 вересня 2005 року № 2850-IV [34]; «Про засади державної регіональної політики» від 5 лютого 2015 року № 156-VIII [20]; «Про співробітництво територіальних громад» від 17 червня 2014 року № 1508-VII [33]; «Про добровільне об’єднання територіальних громад» від 5 лютого 2015 року № 157-VIII [19]; «Про місцеве самоврядування в Україні» від 21 травня 1997 року № 280/97-ВР [31];

4) постанов Кабінету Міністрів України: «Про затвердження Порядку розміщення тимчасово вільних коштів місцевих бюджетів на вкладних (депозитних) рахунках у банках» від 12 січня 2011 р. № 6 [26]; «Про затвердження Порядку складання, розгляду, затвердження та основних вимог до виконання кошторисів бюджетних установ» від 28 лютого 2002 р. № 228 [28]; «Про затвердження Порядку обслуговування коштів місцевих бюджетів у частині бюджету розвитку та власних надходжень бюджетних установ в установах банків державного сектору» від 14 травня 2015 р. № 378 [23]; «Про затвердження Порядку покриття тимчасових касових розривів місцевих бюджетів» від 29 грудня 2010 р. № 1204 [24]; Розпорядження Кабінету Міністрів України «Про схвалення Концепції реформування місцевих бюджетів» від 23 травня 2007 р. № 308-p [35];

5) наказів Міністерства фінансів України: «Про затвердження форм документів для надання позик на покриття тимчасових касових розривів місцевих бюджетів» від 22.06.2012 № 756 [29]; «Про затвердження Порядку казначейського обслуговування місцевих бюджетів» від 23.08.2012 № 938 [22]; «Про затвердження Порядку складання бюджетної звітності розпорядниками та одержувачами бюджетних коштів, звітності фондами загальнообов'язкового державного соціального і пенсійного страхування» від 24.01.2012 № 44 [27]; «Про затвердження Порядку реєстрації та обліку бюджетних зобов'язань розпорядників бюджетних коштів та одержувачів бюджетних коштів в органах Державної казначейської служби України» від 02.03.2012 № 309 [25]; «Про затвердження форм документів для надання позик на покриття тимчасових касових розривів місцевих бюджетів» від 22.06.2012 № 756 [29]; «Про затвердження форм розрахунків при здійсненні місцевих запозичень» від 22.10.2015 № 922 [30]; «Про затвердження Методичних рекомендацій щодо здійснення оцінки ефективності бюджетних програм» від 17.05.2011 № 608 [21];

6) нормативно-правових актів органів виконавчої влади, прийнятих на підставі і на виконання БКУ, інших законів України та нормативно-правових актів КМУ;

7) рішень державних місцевих адміністрацій та органів місцевого самоврядування щодо виконання місцевих бюджетів.

У сучасних умовах демократичного розвитку та реформ децентралізації державного управління у сфері бюджету та фінансів держава загалом сформувала належну нормативно-правову базу. Проте більшість нормативно-правових актів є застарілими, частина положень яких характеризується невідповідністю та суперечливістю, що потребує законодавчих змін у частині розподілу владних повноважень між місцевими державними адміністраціями та органами місцевого самоврядування стосовно формування та розподілу коштів.

К.А. Польшинська зауважує, що в умовах економічної кризи в Україні правове регулювання видатків місцевих бюджетів повинно бути чітким та злагодженим, для того щоб виділені кошти з бюджетів потрапляли за своїм призначенням та в необхідному обсязі задовольняли потреби країни та її населення [17, с. 212].

На нашу думку, реформування місцевих державних адміністрацій має бути зорієнтоване на: впровадження дієвого механізму реалізації повноважень місцевих державних адміністрацій у галузі бюджету та фінансів; дотримання бюджетного законодавства; принципів формування та розподілу державних коштів, контроль владних повноважень.

Удосконалення процесів формування місцевих бюджетів та фінансів в Україні повинне лежати в площині удосконалення законодавства, ліквідації деформацій у фінансовій системі, що сформовані у попередній період, розширення повноважень місцевих державних адміністрацій. Формування, розподіл та використання фінансових ресурсів є необхідним для реалізації місцевими державними адміністраціями покладених на них завдань.

Висновки та перспективи подальших досліджень. Адміністративно-правовий механізм реалізації повноважень місцевих державних адміністрацій у галузі бюджету та фінансів представлений сукупністю структурних елементів, які взаємодіють між собою та спрямовані на виконання соціально-економічної функції держави стосовно розвитку місцевих громад. Важливо відзначити, що з'єднуючою складовою частиною $є$ адміністративно-правові норми, які визначають обов'язки відповідних суб'єктів публічних відносин стосовно формування доходів і видатків місцевих бюджетів, а також засоби та принципи такої діяльності, що дає можливість ефективно забезпечити реалізацію державної економічної політики. 
Можна окреслити важливі напрями, які стоять перед адміністративно-правовим механізмом реалізації повноважень місцевих державних адміністрацій у галузі бюджету та фінансів: 1) розробка сучасної моделі контрольно-наглядової діяльності за виконанням місцевого бюджету; 2) децентралізація повноважень та фінансових потоків; 3) запровадження заходів безпеки у бюджетний процес; 4) приведення чинного законодавства у відповідність зі змінами державної економічної політики у цій сфері, які визначені в урядових документах; 5) утворення нового органу - громадської спостережної ради за розподілом коштів місцевого бюджету.

Тому адміністративно-правовий механізм реалізації повноважень місцевих державних адміністрацій у галузі бюджету та фінансів у загальному розумінні $є$ процесом трансформації норм права та положень законодавства в певну зумовлену упорядкованість суспільних відносин у соціально-економічній сфері за допомогою застосування юридичних методів, засобів, форм.

Перспективами подальших досліджень може бути вивчення юридичних гарантій діяльності державних місцевих адміністрацій у галузі бюджету та фінансів.

\section{Список використаних джерел:}

1. Бойко Т.А. Необхідність бюджетного регулювання в ринкових умовах господарювання. Культура народов Причерноморья. 2008. № 126. С. 14-16.

2. Бюджетний кодекс України від 8 липня 2010 року № 2456-VI. URL: https://zakon.rada.gov.ua/laws/show/2456-17/ed20150920\#Text.

3. Вовчок I.I. Бюджетне регулювання в умовах децентралізації фінансових ресурсів. Економіка та митно-правові відносини. 2017. № 2. С. 32-40.

4. Дмитренко Г.В. Основні принципи формування місцевих бюджетів (на прикладі м. Буча). Економіка та держава. 2012. № 4. C. 119-122. URL: http://nbuv.gov.ua/UJRN/ecde_2012_4_37.

5. Долінська Р.Г. Державні фінанси : навчальний посібник для студентів інженерно-економічних спеціальностей, слухачів післявузівської системи навчання, аспірантів і спеціалістів. Харків : НТУ «ХПІ», 2002 р. 232 с.

6. Завадський Й.С., Осовська Т.В., Юшкевич О.О. Економічний словник. Київ : Кондор, 2006. $355 \mathrm{c}$.

7. Захожай К.В. Принципи побудови Державного бюджету України: процесно-системний підхід. Проблеми економіки. 2017. № 3. C. 47-54. URL: http://nbuv.gov.ua/UJRN/Pekon_2017_3_7.

8. Конституція України від 28 червня 1996 року. URL: https://zakon.rada.gov.ua/laws/ show/254к/96-вр\#Tехt.

9. Кривицький Ю.В. Механізм правового регулювання в сучасній теорії права. Часопис Киівського університету права. 2009. № 4. С. 74-79.

10. Куракін О.М. Механізм правового регулювання: теоретико-правова модель : автореф. дис. ... д-ра юрид. наук : 12.00.01. Харків : Харківський нац. ун-т внутрішніх справ, 2016. 40 с.

11. Лисяк Л.В. Бюджетна політика у системі державного регулювання соціально-економічного розвитку України. Київ : ДННУ АФУ, 2009. 600 с.

12. Місцеві фінанси : підручник / за ред. д.е.н., проф. О.П. Кириленко. 2-ге вид., доп. і перероб. Тернопіль : Економічна думка ТНЕУ, 2014. 448 с.

13. Панченко В.А., Галета Я.В., Черненко О.В. Основи менеджменту : навчальний посібник для студентів економічних спеціальностей. Дніпро : Середняк Т.К., 2019. 452 с.

14. Панчук Н.А. Повышение эффективности государственного регулирования экономики отраслей АПК : автореф. дис. на соискание науч. степени канд. экон. наук : спец. 08.00.05. Москва, 2011.

15. Перощук 3.I. Принципи правового регулювання бюджетної системи України. Hayковий вісник Ужгородського університету. Серія: Право. Ужгород : Вид-во УжНУ «Говерла», 2011. Вип. 17. С. 149-153.

16. Податковий кодекс України від 2 грудня 2010 року № 2755-VI. URL: https://zakon.rada.gov.ua/laws/show/2755-17.

17. Польшинська К.А. Поняття та сутність правового регулювання видатків місцевих бюджетів. Молодий вчений. 2016. № 2. C. 209-213. URL: http://nbuv.gov.ua/UJRN/molv_2016_2_51.

18. Про Державний бюджет України : Закон України від 15 грудня 2020 року № $\overline{10} \overline{2}$-IX. URL: https://zakon.rada.gov.ua/laws/show/1082-20\#Text.

19.Про добровільне об'єднання територіальних громад : Закон України від 5 лютого 2015 року № 157-VIII. URL: https://zakon.rada.gov.ua/laws/show/157-19\#Text. 
20. Про засади державної регіональної політики : Закон України від 5 лютого 2015 року № 156-VIII. URL: https://zakon.rada.gov.ua/laws/show/156-19\#Text.

21.Про затвердження Методичних рекомендацій щодо здійснення оцінки ефективності бюджетних програм : Наказ Міністерства фінансів України від 17.05.2011 № 608. URL: https://zakon.rada.gov.ua/rada/show/v0608201-11\#Text.

22. Про затвердження Порядку казначейського обслуговування місцевих бюджетів : Наказ Міністерства фінансів України від 23.08.2012 № 938. URL: https://zakon.rada.gov.ua/laws/show/ z1569-12\#Text.

23. Про затвердження Порядку обслуговування коштів місцевих бюджетів у частині бюджету розвитку та власних надходжень бюджетних установ в установах банків державного сектору : Постанова Кабінету Міністрів України від 14 травня 2015 p. № 378. URL: https://zakon.rada. gov.ua/laws/show/378-2015-п\#Text.

24. Про затвердження Порядку покриття тимчасових касових розривів місцевих бюджетів : Постанова Кабінету Міністрів України від 29 грудня 2010 p. № 1204. URL: https://zakon.rada. gov.ua/laws/show/1204-2010-п\#Text.

25. Про затвердження Порядку реєстрації та обліку бюджетних зобов'язань розпорядників бюджетних коштів та одержувачів бюджетних коштів в органах Державної казначейської служби України : Наказ Міністерства фінансів України від 02.03.2012 № 309. URL: https://zakon.rada.gov. ua/laws/show/z0419-12\#Text.

26. Про затвердження Порядку розміщення тимчасово вільних коштів місцевих бюджетів на вкладних (депозитних) рахунках у банках : Постанова Кабінету Міністрів України від 12 січня 2011 p. № 6. URL: https://zakon.rada.gov.ua/laws/show/6-2011-п\#Text.

27. Про затвердження Порядку складання бюджетної звітності розпорядниками та одержувачами бюджетних коштів, звітності фондами загальнообов'язкового державного соціального і пенсійного страхування : Наказ Міністерства фінансів України від 24.01.2012 № 44 . URL: https://zakon.rada.gov.ua/laws/show/z0196-12\#Text.

28. Про затвердження Порядку складання, розгляду, затвердження та основних вимог до виконання кошторисів : Постанова Кабінету Міністрів України від 28 лютого 2002 р. № 228. URL: https://zakon.rada.gov.ua/laws/show/228-2002-п\#Text.

29. Про затвердження форм документів для надання позик на покриття тимчасових касових розривів місцевих бюджетів : Наказ Міністерства фінансів України від 22.06.2012 № 756. URL: https://zakon.rada.gov.ua/laws/show/z1179-12\#Text.

30. Про затвердження форм розрахунків у разі здійснення місцевих запозичень : Наказ Міністерства фінансів України від 22.10.2015 № 922. URL: https://zakon.rada.gov.ua/laws/show/ z1354-15\#Text.

31.Про місцеве самоврядування в Україні : Закон України. 21 травня 1997 року № 280/97-BP. URL: https://zakon.rada.gov.ua/laws/show/280/97-вp\#Text.

32. Про місцеві державні адміністрації : Закон України від 9 квітня 1999 року № 586-XIV. URL: https://zakon.rada.gov.ua/laws/show/586-14\#Text.

33. Про співробітництво територіальних громад : Закон України від 17 червня 2014 року № 1508-VII. URL: https://zakon.rada.gov.ua/laws/show/1508-18\#Text.

34. Про стимулювання розвитку регіонів : Закон України від 8 вересня 2005 року № 2850IV. URL: https://zakon.rada.gov.ua/laws/show/2850-15\#Text.

35. Про схвалення Концепції реформування місцевих бюджетів : Розпорядження Кабінету Міністрів України від 23 травня 2007 р. № 308-p. URL: https://zakon.rada.gov.ua/laws/show/ 308-2007-p\#Text.

36. Скакун О.Ф. Теорія держави і права : підручник. / Пер. з рос. Харків : Консул, 2001. 656 с.

37. Чечель О.М. Принципи та механізм державного регулювання економіки. Демократичне врядування. 2014. Вип. 13. URL: http://nbuv.gov.ua/UJRN/DeVr_2014_13_8.

38. Що має знати депутат місцевої ради. Книга 3. Бюджет і бюджетний процес на рівні місцевого самоврядування в Україні : навчальний посібник Київ : ІПО, 2011. 160 с. 